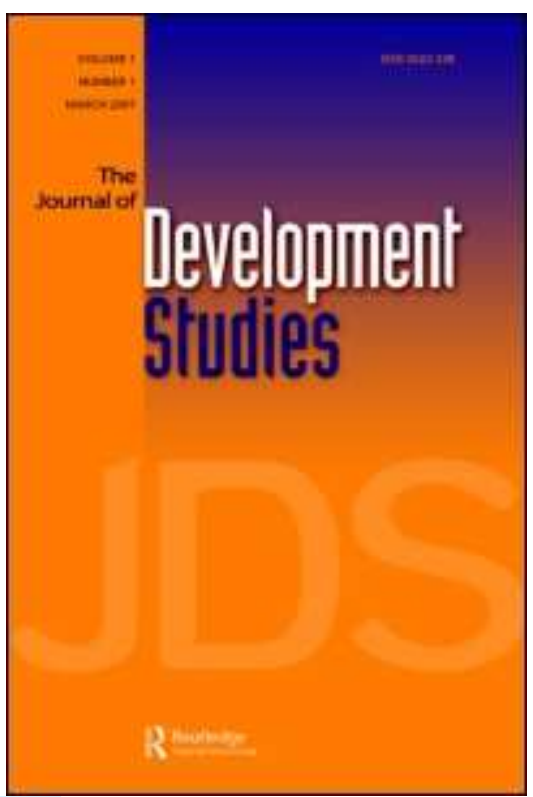

\title{
Gender and Trade Aspects of Labour Markets
}

\begin{tabular}{|r|l|}
\hline Journal: & Journal of Development Studies \\
\hline Manuscript ID: & FJDS-2009-May-0025.R3 \\
\hline Manuscript Type: & Original Manuscripts \\
\hline Keywords: & $\begin{array}{l}\text { Trade < Economics, Gender }<\text { Social Issues, Workers }< \\
\text { Employment and Law, Globalisation < Social Issues }\end{array}$ \\
\hline
\end{tabular}

\section{SCHOLARONE Manuscripts}




\title{
Survey Paper: Gender and Trade Aspects of Labour Markets
}

\begin{abstract}
We provide a comprehensive up-to-date review of the large body of theory and evidence on the linkages between trade liberalisation and gender inequality in income, as well as two of the latter's key underlying determinants: wages and employment. On balance, the evidence for developing countries points to an overall beneficial impact of trade expansion on female employment, both relative to male employment and in absolute terms, although largely concentrated in unskilled manufacturing. By contrast, the bulk of the evidence suggests a widening gender wage gap as a result of freer trade.
\end{abstract}

\author{
Keywords: Trade, Gender, Income, Wages, Employment \\ JEL classification: E21, F14, J16, J81.
}

$\sim 1 \sim$ 


\section{INTRODUCTION}

In recent decades freer trade has been regarded as the 'royal highway' to fostering economic growth and reducing poverty, and trade liberalisation has been one of the main prescriptions of the 'Washington Consensus' on reform measures required for ailing economies. Reductions in tariffs, the establishment of the World Trade Organization and free-trade zones (NAFTA, EU-EEA, MERCOSUR), the reduction in capital controls and subsidies and the harmonisation in intellectual property right laws have all contributed to a multi-fold increase in the global volume of trade.

Economists tend to view trade expansion as an opportunity to achieve a more efficient allocation of resources, and enhance productivity and employment levels. While trade theorists generally point to the potential of trade expansion to benefit the economy as a whole, they also draw attention to the fact that not everyone benefits equally. Trade has differential impacts across socio-economic groups, geographical regions, productive sectors and, the focus here, the two sexes (Elson et al., 2007).

The evidence on linkages between on the one hand trade liberalisation and expansion, and on the other gender inequality is reviewed in this paper and is found to be highly diverse. The focus of the paper is primarily on gender inequality in income and two of its key underlying determinants: wages and employment. Although gender inequality in other domains is touched on, expanding the analysis towards these domains would be at the expense of an in-depth discussion of the already extensive literature on gender inequality in income and trade within the confines of a single paper (in the online appendix we briefly discuss evidence on the impact of trade expansion on gender inequality in domains other than income). There have been earlier surveys of the literature on gender inequality and trade (Çağatay, 2001; Fontana, 2003; Tran-Nyugen and Bevigilia Zampetti, 2004). Our contribution is twofold. First, we update these surveys with more recent evidence on the impact of trade on gender inequality (and vice versa), while reviewing the methodological characteristics of the empirical studies. Secondly, and more importantly, the paper links the theoretical findings on trade-gender links with the empirical evidence of econometric studies in the field. In Section 2, we discuss in detail the theoretical mechanisms linking 
trade expansion and gender inequality in income, as identified within the literature on trade and labour economics. In Section 3, we critically examine the evidence (including case-studies) that exists in relation to the theoretical links presented in the previous section. Section 4 concludes by highlighting gaps in current knowledge of trade and gender aspects of labour markets.

\section{GENDER AND TRADE: THEORY}

Women and men are often exposed to trade expansion in different ways (Ghiara, 1999; Kucera and Milberg, 2000; Fontana, 2007). The impact of trade on gender equality is complex, with many factors simultaneously at work. Trade expansion affects relative prices, income levels, employment patterns, the size of productive sectors, and all these may in turn have gendered implications as we will discuss below. In addition, existing gender inequality co-determines comparative advantage and thereby the sectors in which a country will specialise for exports.

We outline in this section a basic framework presenting the theoretical mechanisms through which trade expansion can affect gender inequality in income (and its underlying determinants, for example, employment, asset ownership, changes in factor prices). The plausible reverse causality running from gender inequality to trade expansion is also briefly discussed at the end of this section. A natural step to begin with is by linking gender inequality in income to inequality in the ownership of production factors (for example, labour, human and physical capital, land) as well as their corresponding returns, similar to Anderson (2005). In algebraic terms one can define (and decompose) income by gender as:

$$
Y_{j}=r_{1 j} w_{1 j} P_{1}+\ldots+r_{i j} w_{i j} P_{i}
$$

where $Y_{j}$ is income received by gender ( $j=f, m$ : $f$ for the female and $m$ for the male population), $P_{i}$ stands for the overall endowment of any production factor $i$ in the economy, $w_{i j}$ captures the share of ownership of each production factor by gender and $r_{i j}$ is the gender-specific return to each factor of production. A ratio of female-earned income over its male counterpart (that is, $Y_{f} / Y_{m}$ ) below one suggests the presence of gender inequality in income in favour of the male population. 
Equation (1) serves as a framework to organise the discussion below, focusing on gender-specific ownership of and returns on production factors, which may vary by sector or industry. It is then useful to distinguish two types of effects: namely inter- and intra-industry gendered impacts (see Tejani and Milberg, 2010). Intra-industry effects relate to gendered impacts within a given industry, for example, when trade liberalisation exacerbates male-female wage gaps in a particular industry, often for employees with very similar characteristics. On the other hand, inter-industry effects pertain to the relative size of different sectors (that is, the structure of the economy) that vary in patterns of ownership by gender of production factors. For the latter type of effect, the crux is whether trade expansion corresponds with an expansion or contraction of female(male)-intensive sectors. For neither intra- nor inter-industry gendered effects of trade is it necessary to assume that trade is inherently gender biased; it may simply reinforce or exacerbate existing patterns of gender inequality embedded in the labour market.

Even as a neutral force whose immediate effect is only on the balance of economic activities, trade, through the labour market, interacts with a host of social and economic factors to bring about gendered impacts. The initial feminisation/masculinisation of particular sectors, as well as subsequent resistance (or not) in achieving a gender-neutral sorting in job access, is partly linked to gendered access to productive assets (time, credit, land, human capital) as well as gender norms and stereotypes that result in an implicit segregation of occupations by gender. Hence, while economic reasoning (for example, differences in educational attainment) may for instance explain to some extent gender segregation across sectors, perceptions on differential abilities of the sexes (for example, with regard to the capacity to carry out physical or repetitive work) further contribute to such trends. This interplay of economic characteristics and gender norms and stereotypes influences firms' hiring practices and often results in women being concentrated in sectors where workers face a lower pay and less security (particularly in sectors that face a high price elasticity of demand as a result of intense international competition).

We will now turn our attention to the predictions of economic theory with respect to the impacts of trade expansion on gender inequality and its underlying determinants, using the framework developed above to organise the discussion. 


\subsection{Factor prices $\left(r_{i j}\right)$}

Let us assume that returns to factors of production do not vary across men and women $\left(r_{i f}=r_{i m}\right)$, an assumption that we will relax as the analysis proceeds. Conventional trade theory suggests that economies specialise in sectors that make intensive use of relatively abundant production factors. The HeckscherOhlin (HO) model assumes that if a country is more abundant in, say, production factor $k$ (capital) than $l$ (labour) (that is, the ratio $P_{k} / P_{l}$ for that specific economy is larger than the one of its trading partner), then freer trade will lead to an expansion of those sectors that make intensive use of the relatively abundant factor $k$ (with a corresponding contraction of those sectors that depend on the relatively scarce factor l). Several findings of the HO model can be relevant in terms of gender equity (although one should keep in mind that the HO model can only provide an initial - and often incomplete - framework for analysis on gendered impacts, unless enriched with elements that explicitly capture salient gender dynamics in the labour market, that relate to issues of discrimination, job segregation and unemployment across sexes). The expansion of exports, as a result of freer trade, will increase the relative prices of exported commodities, the relative demand for factors used intensively in their production, and subsequently will raise their relative return (in our previous example $r_{k} / r_{l}$ will increase; this is the standard prediction of the Stolper-Samuelson theorem $)^{1}$. In the HO model, a country that is relatively abundant in unskilled labour and where women account for a disproportionately larger share of unskilled labourers will hence experience an increase in wages and income for the female labour force relative to their relatively skilled male counterparts.

\section{Monopsony - Discrimination $\left(r_{i f} \neq r_{i m}\right)$}

A stream of influential work on labour market frictions has recently focused on labour demand and the monopsony power of employers to explain the gender wage gap (male wages exceeding female wages, with the gap commonly expressed as a share of the former). Much of this work has been pioneered by Manning (2003), who explored theoretically the implications for gender wage inequality of market power of employers over their workers. Manning's theory of labour monopsony has close links to the theoretical 
extensions of the HO model with unemployment (which we touch upon in the next subsection) and also assumes that the discriminatory power of the employer depends on the wage elasticity of the labour supply (Manning, 2003; Bhaskar et al., 2002). The crux is that female workers may be more prepared than males to accept lower wages set by their firm, if they are more reluctant than men to switch jobs (to avoid search costs in the form of time and foregone income).

An outline of his theory is as follows. Firms may have considerable power in setting the wage level, particularly for workers with low skills (whose labour input is not differentiated). Employers may hence become discriminating monopsonists, creating a wage gap for workers of identical skills (but discrimination can also come in other forms, such as hours of work, work conditions and so forth). Manning (2003, ch7) claims that the market for female labour is more likely to be monopsonistic than the male one, as women will have a less elastic labour supply with respect to wages, for two reasons. First, women may have a lower reservation wage (defined as the lowest wage at which a job offer will be accepted), as their job mobility is constrained by their parallel involvement in reproductive activities. Second, they often have less time available for job searching, (re)training and commuting, with their job choices motivated to a large extent by factors beyond the level of wage (for example, distance to work). In Manning's model, employers take advantage of women's relatively inelastic labour supply, thus creating a gender wage gap (which has indeed been found to be larger for those married with children, see Waldfogel, 1998).

There also other theories of monopsonistic discrimination, such as the one by Black (1995) that suggests that the unwillingness by a proportion of employers to hire women (as a result of prejudice) makes the female labour market less competitive and allows even the 'non-prejudiced' firms to wage discriminate against them. The important point to take for our purposes is that if monopsonistic conditions prevail in the female labour market, the gender wage gap may not decrease even if female employment increases as a result of freer trade ${ }^{2}$.

By contrast, Becker's (1971) renowned theory emphasises that when competition among firms increases, wage premia in favour of male workers become unaffordable. Imperfect competition allows 
gender-based wage discrimination, which should gradually disappear as competition intensifies as a result of trade. The insight uniting each of the theories discussed in this subsection is that in non-competitive environments, resulting from limited competition due to barriers to entry, employers are able to afford satisfying discriminatory preferences in terms of gender. The difference between them is that in Becker's theory trade expansion always helps to alter the structure of the labour market in the direction of perfect competition, whereas it doesn't in Manning's and Black's theories, which explains why in the latter case the gender wage gap may be more sticky.

\subsection{Share of production factors $\left(w_{i j}\right)$}

The ownership of production factors by gender is a crucial factor in understanding changes in gender income inequality as a result of trade openness. For instance, freer trade can improve the relative income position of women if the economy has a comparative advantage in goods that make intensive use of unskilled labour, and if women are relatively more often the 'owners' of the production factor unskilled labour compared to other productive assets - for example, capital, that is more often male-controlled.

Furthermore, individuals will have an incentive to skew their ownership of assets towards the abundant production factor, if freer trade gradually raises the relative demand and price of it. Acquisition of new assets is costly though (both in monetary and time terms), and women's accumulation of factors of production may be less responsive to positive changes in their prices if they face more constraints than men do in access to credit (as a result of a lower initial level of asset endowments/collateral) or if their domestic tasks leave them 'time poor' ${ }^{3}$. The monetary constraints may be relaxed when trade expands, for example, as a result of increased wages of unskilled labour that may disproportionately benefit the female labour force. On the other hand, when women's role is widely perceived to be confined to reproductive tasks and they receive limited support in carrying them out when they engage in other activities (Anker, 1997), the time constraints on acquiring productive assets (such as skills) may prove to be more durable.

Unemployment in the HO model 
Although most HO models of trade abstract from discussing unemployment, a rise in the relative demand for any abundant (but underemployed) production factor will naturally increase its rate of employment in the economy. Changes in employment have received particular interest in models that integrate imperfections in labour markets and unemployment in the HO context (Davidson et al., 1988; Davidson and Matusz, 2010). This type of analysis has particular relevance when one considers the gender-specific impacts of trade on employment. Whether expanding sectors in accordance with the comparative advantage of the economy that could in principle contribute to increased female (relative to male) employment (that is, $w_{l f}$ ) will do so in practice may depend to a large extent on implicit constraints on labour participation. One needs to incorporate insights from the labour economics literature to fully capture the speed and efficiency of adjustment in the labour markets that takes place as a result of trade openness. Search and training processes, which are necessary in order for workers to acquire sectorspecific skills and efficiently seek employment (and/or relocate in the case of trade-induced structural changes) can be very costly, particularly for women, who may have limited access to time, credit or other assets to finance such a transition, and who may also be discouraged more directly from seeking employment ${ }^{4}$.

Labour market imperfections are thus one reason why female employment may not respond as much as it could to trade expansion, which is another way of saying that an economy's comparative advantage is not fully realised. Suppose the scenario of an economy with a comparative advantage in sectors with more job insecurity and harsher working conditions than the rest of the economy. Since changing jobs is costly, already employed labour is correspondingly more inelastic to changes in wages, with unemployed workers (sometimes more often women, other times men) more prepared to fill in new employment opportunities that arise in these expanding sectors (Davidson et al., 1999). However, if in due course higher wages are required to compensate in part for the uncertainty workers face in these sectors, the corresponding increase in production costs can skew the pattern of comparative advantage away from initially competitive commodities (see Davison and Matusz, 2010, ch.7). 
The analysis of the effect of trade on employment by gender may be complicated by the fact that trade expansion typically takes place in the context of a host of macroeconomic policies that stimulate it as well as other correlates of globalisation, such as the freer movement of capital (in the form of foreign direct investment). Many multinational firms adopt production strategies designed to reduce labour costs by outsourcing part of their production abroad (through 'firm disintegration'), where they often make use of subcontracted labour through informal and temporary-basis labour agreements (which women are more likely to accept facing a relatively lower reservation wage; see Ghosh, 2001; Balakrishnan, 2002; Sayeed and Balakrishnan, 2002; Elson et al., 2007). Women are then often treated as 'buffer employment' whose demand varies to accommodate the particular needs for manual labour during different stages of the business cycle; Kucera (2001) for instance gives evidence on a higher ratio of women to men in temporary employment in Germany and Japan in the 80s and 90s, with temporary workers perceived as a flexibility mechanism in the face of demand fluctuations. As we will discuss below, the weaker position of women in negotiating wages and secure employment has itself helped shape particular export strategies and comparative advantage for several countries.

\section{Gender Impacts on Trade}

Causal mechanisms relating trade and gender can run in both directions. Gender inequality in terms of wages and labour rights may affect the pattern of comparative advantage and hence trade expansion and specialisation in specific commodities. Lower female wages in export-oriented industries, for instance, created a comparative advantage in labour-intensive commodities (and stimulated export-led growth) for many East-Asian economies (Seguino, 1997, 2000a, b). Intense competition in international markets, especially for commodities whose demand is strongly responsive to price fluctuations, has exerted pressure on trading firms to curb labour costs and has disproportionately affected wages of female workers, whose bargaining power is often weaker.

In that respect, the export-led growth miracle model of Taiwan was supported by lower female wages to maintain the competitiveness of domestic industries and shield them from intense international 
competition in commodity markets and capital flight (Rodrik, 2000; Seguino, 1997, 2000a, 2007a). Busse and Spielmann (2006) obtain compatible cross-country results regarding the impact of gender inequality on creating comparative advantage in labour-intensive industries. They find that a 1 per cent increase in the gender wage gap increases the share of labour-intensive exports in total exports by 0.3-0.4 per cent (for the year 2000). Nevertheless, it is fair to mention that as trade expands, any positive effect on the level of female wages (even with a persistent level of a gender wage gap), is likely to make alternative policies (to gendered wage-discrimination) necessary to stimulate investment, increase productivity and preserve competitiveness. Seguino (2000a), for instance, points out that Korea gradually had to rely increasingly more on domestic savings for its industrial expansion and its firms steadily shifted focus towards improving technologies in use to preserve competitiveness of their products rather than cuts in labour costs. 


\section{GENDER AND TRADE: EvidENCE}

The purpose of this section is to critically evaluate empirical studies undertaken in recent years that provide evidence on the linkages between trade openness and gender inequality in income, as well as its underlying determinants: that is, the ownership of production factors and their prices $\left(w_{i j}, r_{i j}\right)$. We present the evidence following the classification of the theoretical links presented in Section 2, and assess if the evidence supports the theoretical links.

Studies in this field vary considerably in their choice of dependent variable but may generally be said to explore causal mechanisms of the following generic form:

$$
G_{i}=\alpha_{0}+\alpha_{1} T_{i}+\alpha_{2} T_{i} \cdot X_{i}
$$

where $G_{i}$ is a gender-specific variable (that may capture either the absolute or relative position of women with respect to employment, income, wages and so forth), $T_{i}$ captures openness to international trade, $X_{i}$ is the set of mediating factors that influence the magnitude and sign of the overall effect and where the subscript $i$ corresponds to each country in the sample or case study. A positive coefficient for $\alpha_{1}$ would hence capture a beneficial impact of trade for women (which depending on the outcome variable may suggest an increase in female employment either in absolute or relative terms, a rise in female wages or a closing of the gender wage gap). If one expects trade openness to reduce gender inequality in developing countries, but have the opposite effect for developed economies, $X$ may include a measure of economic development $Y$ (for example, GDP per capita). This expectation could be motivated by the HO model, which assumes that developing countries are likely to specialise more in unskilled-labour intensive production, with unskilled labour comparatively (that is, compared to the other production factors) often being a production factor 'owned' by women. By contrast, specialisation in high skilled and capital intensive commodities in developed economies may increase gender inequality to the extent that men comparatively own the respective production factors. Support for this hypothesis would hence require that $\alpha_{2(\mathrm{Y})}<0$, where $\alpha_{2(\mathrm{Y})}$ captures the extent to which a country's level of development affects the impact of trade openness on women. This is examined in some of the studies reviewed below. 
Other studies explore similar hypotheses based on HO assumptions by explicitly focussing on relative factor endowments, comparative advantage and the sectoral division of the economy. Hence, the higher the relative endowment of a production factor that is more equally distributed between men and women, the higher is likely to be the impact of trade openness on improving gender equality. In this case $X$ may include a measure of the relative abundance of a comparatively equitably distributed production factor (for example, the share of labour to capital, $P_{l} / P_{k}$ ), possibly weighted by a measure of (in)equity in the distribution of its ownership between men and women (that is, $w_{l f} / w_{l m}$ ), and/or an analogous measure of the ownership of the other production factor (that is, $w_{k f} / w_{k m}$ ). Support for this hypothesis would require that $\alpha_{2(\mathrm{P})}>0$, where $\alpha_{2(\mathrm{P})}$ captures the extent of relative abundance in the economy of the production factor that is comparatively often female-owned. In other words, the relative availability of production factors shapes the product specialisation patterns of individual countries, while the gendered control of these factors at an individual level influences the inequality between men and women in their capability to take advantage of opportunities arising from trade expansion.

\subsection{Factor prices $\left(r_{i j}\right)$ - Wages}

There has been much research devoted to the impact of trade openness on the gender wage gap and the wage of unskilled relative to skilled labour (with the latter being disproportionately male in its composition). We present details of some of the key studies in Table 1. Several of them suggest that the impact of trade expansion on female wages largely depends on the sector in which women find employment, with manufacturing offering better prospects than others. Evidence from Mexico, Bangladesh and Madagascar, especially for uneducated female employees, suggests that employment in export manufacturing industries provides female workers with higher wages compared to other activities (Tiano, 1994; Fussel, 2000; Kabeer and Mahmud, 2004; Glick and Roubaud, 2006; Fontana, 2007), without suggesting that the gender wage gap necessarily narrows. Subcontracted home-based workers, however, are a general exception to this pattern. Home-based workers in the informal sector (the majority 
of which are usually women) receive lower earnings compared to employees in the formal private sector and have to incur the set-up and operational costs to start production (Carr et al., 2000; Ghosh, 2001).

However, not all women receive direct payments for their labour contributions in trade-related activities. In many cases where agricultural production is outsourced by multinational companies (or intermediary firms) to individual households, it is often the male head of the household who negotiates terms, holds the contract and receives all payments from the export company (Fontana, 2003). This pattern is generally more prevalent in export vegetable production, while waged formal labour tends to be more common in the fruit and flower sector (Barrientos et al., 2004). Even when women receive direct payments for their involvement in agriculture, in countries such as Bangladesh and Pakistan, it is a common practice to hand over their earnings to their husbands (Elson, 1999). Physical proximity of spouses appears to matter, too, since women working away from their partners are more likely to receive directly payments for their employment (Kabeer, 2000).

While trade often offers women an opportunity to receive own income, this does not necessarily translate into a closing of the gender wage gap. Although not separately quantified for export-orientated sectors, Joekes (1999) finds that female as a percentage of male earnings in a selected group of developing countries ranges from 50 to 80 per cent, about half of which may be attributed to discrimination, the remainder to job segregation and educational attainments. While female employees especially in the exporting manufacturing industries often receive higher wages than women in other industries, the wage gap between male and female workers expressed as a share of the former (even when performing similar tasks in comparable sectors) tends to be large, often above 50 per cent (Carr et al., 2000; Fleck, 2001; Artecona and Cunningham, 2002; Menon and Rodgers, 2009), and is frequently found to be widening, particularly in developing countries. In a number of studies it has been observed (Ghiara, 1999; Fleck, 2001; Artecona and Cunningham, 2002; Nicita and Razzaz, 2003) that in exporting industries, such as textiles and electronics, wages for skilled workers grow proportionately faster than those of unskilled employees. Since the unskilled labour force is dominated by women, this trend of increasing skill premia widens the gap between the wages of male and female workers ${ }^{5}$. Likewise, results from the 1997 survey 
on socioeconomic and health conditions of garment workers in Bangladesh reveal that there are gender wage differences in every job category in the garment industry (a particularly export-orientated sector), which have consistently increased over time (Paul-Majumder and Begum, 2000). Similarly, while female employment has increased in recent years in China, there has been a simultaneous widening of the gender wage gap, only partially explained by gender productivity differences (Maurer-Fazio and Hughes, 2002; Braunstein and Brenner, 2007), and exacerbated by the gradual liberalisation of markets and expansion of private ownership that enhanced the monopsonistic wage-setting power of firm managers, and suppressed female wages ${ }^{6}$.

On the other hand, there is some evidence (supporting Becker's theory) that the gender wage gap has diminished in export-oriented manufacturing industries in industrialised nations such as the US as a result of increased exposure to competition (Black and Brainerd, 2004; see also Oostendorp, 2009, who claims that trade decreases the gender wage gap particularly for countries with a sufficiently high level of economic development). However, a recent revisit of the Black and Brainerd study suggests that the reduction of the gender-wage gap across U.S. manufacturing firms was more plausibly due to a decrease of female employment in low-wage production rather than the erosion of this gap in the face of international competition (Kongar 2007; see also Berik et al. 2004 for similar evidence on the gender wage gap in export-oriented manufacturing for South Korea and Taiwan).

Further research along these lines would deepen our understanding of gender-trade linkages. Furthermore, as discussed in Section 2, the causality of the relationship linking trade openness and gender inequality (in wages) runs in both directions, and there is hence a need to properly explore its direction (for example, by the use of time-lagged explanatory variables). More attention has to be devoted to ensure that statistical relationships are not spurious (particularly for those studies that discuss descriptive statistics and simple correlations without performing rigorous econometric analysis with the inclusion of multiple explanatory variables).

Table 1. Studies of the effect of trade on wages 


\begin{tabular}{|c|c|c|c|c|c|c|}
\hline Study & $\begin{array}{c}\text { Direction } \\
\text { of effect }\end{array}$ & Wages & $\begin{array}{l}\text { Measure of } \\
\text { Openness }\end{array}$ & Sector & $\begin{array}{l}\text { Geographical } \\
\text { Focus }\end{array}$ & $\begin{array}{l}\text { Type of } \\
\text { Study }\end{array}$ \\
\hline $\begin{array}{l}\text { Artecona and } \\
\text { Cunningham } \\
\text { (2002) }\end{array}$ & $\begin{array}{l}\alpha_{1}<0 \\
\alpha_{1}>0\end{array}$ & $\begin{array}{l}\text { Relative Female-Male } \\
\text { Discrimination } \\
\text { Component of Wage Gap }\end{array}$ & $\begin{array}{c}\text { Difference in Tariff } \\
\text { Levels and Quota } \\
\text { Rates }\end{array}$ & Manufacturing & $\begin{array}{l}\text { Mexico, } \\
\text { 1987-1993 }\end{array}$ & EC, WS \\
\hline Berik (2007) & $\begin{array}{l}\alpha_{1}<0 \\
\alpha_{1}>0\end{array}$ & $\begin{array}{c}\text { Female } \\
\text { Relative Female-Male }\end{array}$ & $\begin{array}{l}\text { Exports in Output per } \\
\text { Industry }\end{array}$ & Manufacturing & $\begin{array}{c}\text { Taiwan, 1981- } \\
1996\end{array}$ & $\begin{array}{c}\text { EC, WS, } \\
\text { NA }\end{array}$ \\
\hline $\begin{array}{l}\text { Berik et al. } \\
\text { (2004) }\end{array}$ & $\alpha_{1}<0$ & Relative Female-Male & $\begin{array}{l}\text { Imports in Output per } \\
\text { Industry (Taiwan) } \\
\text { Exports in Output per } \\
\text { Industry (South } \\
\text { Korea) }\end{array}$ & Manufacturing & $\begin{array}{c}\text { South Korea, } \\
\text { Taiwan, } \\
\text { 1981-1999 }\end{array}$ & $\begin{array}{c}\text { EC, WS, } \\
\text { NA }\end{array}$ \\
\hline $\begin{array}{l}\text { Black and } \\
\text { Brainerd (2004) }\end{array}$ & $\alpha_{1}>0$ & Relative Female-Male & $\begin{array}{l}\text { Imports in Output per } \\
\text { Industry }\end{array}$ & Manufacturing & $\begin{array}{c}\text { US, } \\
1976-1993\end{array}$ & $\mathrm{EC}, \mathrm{NA}$ \\
\hline $\begin{array}{l}\text { Braunstein and } \\
\text { Brenner (2007) }\end{array}$ & $\alpha_{1}<0$ & Relative Female-Male & $\begin{array}{l}\text { FDI in Total } \\
\text { Investment }\end{array}$ & Cross-Sector & $\begin{array}{l}\text { China, } \\
2002\end{array}$ & $\begin{array}{c}\text { EC, HS, } \\
\text { NA }\end{array}$ \\
\hline $\begin{array}{l}\text { Carr et al. } \\
(2000)\end{array}$ & $\alpha_{1}<0$ & $\begin{array}{c}\text { Female } \\
\text { Relative Female-Male }\end{array}$ & $\begin{array}{l}\text { Adoption of Export- } \\
\text { Led Strategies }\end{array}$ & $\begin{array}{l}\text { Informal (HB): } \\
\text { Garments, NTA }\end{array}$ & $\begin{array}{l}\text { NGF, } \\
1990 \mathrm{~s}\end{array}$ & LR \\
\hline Fleck (2001) & $\alpha_{1}<0$ & Relative Female-Male & $\begin{array}{l}\text { Adoption of Export- } \\
\text { Led Strategies }\end{array}$ & $\begin{array}{l}\text { Manufacturing } \\
\text { (Maquilas) }\end{array}$ & $\begin{array}{c}\text { Mexico, } \\
1997-1998\end{array}$ & $\mathrm{EC}, \mathrm{HS}$ \\
\hline Fontana (2007) & $\begin{array}{l}\alpha_{2(\mathrm{P})}>0 \\
\alpha_{2(\mathrm{P})}>0 \\
\alpha_{2(\mathrm{P})}>0 \\
\alpha_{2(\mathrm{P})}<0\end{array}$ & $\begin{array}{l}\text { Female (Bangladesh) } \\
\text { Relative Female-Male } \\
\text { (Bangladesh) } \\
\text { Female (Zambia) } \\
\text { Relative Female-Male } \\
\text { (Zambia) }\end{array}$ & $\begin{array}{l}\text { Abolition of Tariffs } \\
\text { and Depreciation of } \\
\text { Exchange Rate }\end{array}$ & Cross-Sector & $\begin{array}{c}\text { Bangladesh } \\
\text { 1994, Zambia } \\
1995\end{array}$ & CGE \\
\hline Fussel (2000) & $\alpha_{2(\mathrm{P})}>0$ & Female (Unskilled) & $\begin{array}{l}\text { Adoption of Export- } \\
\text { Led Strategies }\end{array}$ & $\begin{array}{l}\text { Manufacturing } \\
\text { (Maquilas) }\end{array}$ & $\begin{array}{c}\text { Mexico, } \\
1993\end{array}$ & EC, WS \\
\hline Ghiara (1999) & $\alpha_{1} \approx 0$ & Relative Female-Male & $\begin{array}{l}\text { Adoption of Export- } \\
\text { Led Strategies }\end{array}$ & Cross-Sector & $\begin{array}{l}\text { Mexico, } \\
1987-1993\end{array}$ & $\begin{array}{c}\text { EC, WS- } \\
\text { HS }\end{array}$ \\
\hline $\begin{array}{l}\text { Glick and } \\
\text { Roubaud (2006) }\end{array}$ & $\alpha_{1}>0$ & $\begin{array}{c}\text { Female } \\
\text { Relative Female-Male }\end{array}$ & Promotion of EPZs & $\begin{array}{l}\text { Manufacturing } \\
\text { (EPZs) }\end{array}$ & $\begin{array}{c}\text { Madagascar, } \\
1995-2002\end{array}$ & EC, WS \\
\hline $\begin{array}{l}\text { Kabeer and } \\
\text { Mahmud (2004) }\end{array}$ & $\alpha_{1}>0$ & Female & $\begin{array}{l}\text { Adoption of Export- } \\
\text { Led Strategies }\end{array}$ & $\begin{array}{l}\text { Manufacturing } \\
\text { (Textiles) }\end{array}$ & $\begin{array}{l}\text { Bangladesh, } \\
\text { 1980s-2001 }\end{array}$ & DS, HS \\
\hline Kongar (2007) & $\alpha_{1}>0$ & Relative Female-Male & $\begin{array}{l}\text { Imports in Output per } \\
\text { Industry }\end{array}$ & Manufacturing & $\begin{array}{c}\text { US, } \\
1976-1993\end{array}$ & EC, NA \\
\hline $\begin{array}{l}\text { Maurer-Fazio } \\
\text { and Hughes } \\
(2002)\end{array}$ & $\begin{array}{l}\alpha_{1}>0 \\
\alpha_{1}<0\end{array}$ & $\begin{array}{c}\text { Female } \\
\text { Relative Female-Male }\end{array}$ & $\begin{array}{l}\text { Market Liberalisation } \\
\quad \text { (Firm Level) }\end{array}$ & Cross-Sector & $\begin{array}{c}\text { China, } \\
1992\end{array}$ & EC, WS \\
\hline $\begin{array}{l}\text { Menon and } \\
\text { Rodgers (2009) }\end{array}$ & $\alpha_{1}<0$ & Relative Female-Male & $\begin{array}{l}\text { Imports and Exports } \\
\text { in Output per } \\
\text { industry }\end{array}$ & Manufacturing & $\begin{array}{c}\text { India, } \\
1983-2004\end{array}$ & EC, HS \\
\hline $\begin{array}{l}\text { Nicita and } \\
\text { Razzaz (2003) }\end{array}$ & $\begin{array}{l}\alpha_{1}>0 \\
\alpha_{1}<0\end{array}$ & $\begin{array}{c}\text { Female } \\
\text { Relative Female-Male }\end{array}$ & $\begin{array}{l}\text { Adoption of Export- } \\
\text { Led Strategies }\end{array}$ & $\begin{array}{l}\text { Manufacturing } \\
\text { (Textiles) }\end{array}$ & $\begin{array}{c}\text { Madagascar, } \\
1997,1999\end{array}$ & EC, HS \\
\hline $\begin{array}{l}\text { Oostendorp } \\
(2009)\end{array}$ & $\begin{array}{c}\alpha_{1}>0 \\
\alpha_{2(\mathrm{Y})}>0\end{array}$ & $\begin{array}{l}\text { Relative Female-Male } \\
\text { Relative Female-Male }\end{array}$ & $\begin{array}{l}\text { Imports and Exports } \\
\text { in GDP, FDI in GDP }\end{array}$ & Cross-Sector & $\begin{array}{c}\text { D1, D2, } \\
1983-1999 \\
\end{array}$ & EC, NA \\
\hline $\begin{array}{l}\text { Paul-Majumder } \\
\text { and Begum } \\
(2000)\end{array}$ & $\alpha_{1}<0$ & Relative Female-Male & $\begin{array}{l}\text { Adoption of Export- } \\
\text { Led Strategies }\end{array}$ & $\begin{array}{l}\text { Manufacturing } \\
\text { (Textiles) }\end{array}$ & $\begin{array}{c}\text { Bangladesh, } \\
\text { 1990, 1993, } \\
1997\end{array}$ & DS, CS \\
\hline $\begin{array}{l}\text { Santos and } \\
\text { Varejão (2007) }\end{array}$ & $\begin{array}{l}\alpha_{1}>0 \\
\alpha_{1}<0\end{array}$ & $\begin{array}{l}\text { Relative Female-Male } \\
\text { (Overall) } \\
\text { Relative Female-Male } \\
\text { (Tourism) }\end{array}$ & Expansion of Sector & $\begin{array}{l}\text { Services } \\
(\text { Tourism) }\end{array}$ & $\begin{array}{l}\text { Portugal, } \\
2000\end{array}$ & EC, WS \\
\hline Siddiqui (2009) & $\alpha_{2(\mathrm{P})}<0$ & Female (Unskilled) & $\begin{array}{l}\text { Reduction of Tariffs } \\
\qquad 15 \sim\end{array}$ & Cross-Sector & Pakistan, & CGE \\
\hline
\end{tabular}




\begin{tabular}{|c|c|c|c|c|c|c|}
\hline & $\alpha_{1}>0$ & Relative Female-Male & & & 1993 & \\
\hline Thrane (2008) & $\alpha_{1}<0$ & Relative Female-Male & Expansion of Sector & $\begin{array}{l}\text { Services } \\
\text { (Tourism) }\end{array}$ & $\begin{array}{l}\text { Norway, } \\
1994-2002\end{array}$ & EC, WS \\
\hline Tiano (1994) & $\alpha_{1}>0$ & Female & $\begin{array}{l}\text { Adoption of Export- } \\
\text { Led Strategies }\end{array}$ & $\begin{array}{l}\text { Manufacturing } \\
\text { (Maquilas) }\end{array}$ & Mexico, 1990s & $\mathrm{CS}$ \\
\hline
\end{tabular}

Abbreviations: CGE: Computer General Equilibrium Model, CS: Case-Study, D1: Developing Countries, D2: Developed Countries, DS: Descriptive Statistics, EC: Econometrics Analysis, EPZ: Export-Processing Zone, FDI: Foreign Direct Investment, GDP: Gross Domestic Product, HB: Home-Based Work, HS: Household Survey, LR: Literature Review, NA: National Accounts, NGF: No Geographic Focus, NTA: Non-Traditional Agriculture, WS: Worker Survey

\subsection{Share of production factors $\left(w_{i j}\right)$ - Employment}

The empirical research that has attempted to link trade openness with ownership and utilisation rates of production factors has almost exclusively focussed on the impact of trade on employment by gender (although there is also some tentative evidence of a negative link between freer trade and gender inequality in human capital, particularly in Sub-Saharan Africa, as a result of disproportionately high demand for unskilled female labour, see Baliamoune-Lutz, 2006). We present details of some of the key studies in the literature linking trade and employment by gender in Table 2. On balance the evidence points to an overall beneficial impact of trade expansion on female employment in developing economies both in absolute terms (Standing, 1999; Barrientos et al., 2004; Kabeer and Mahmud, 2004; Fontana, 2007) as well as relative to male employment (Ahmed and Bukhari, 2006; Özler, 2007; Ederington et al., 2009), although many studies provide evidence to the contrary (Ghiara, 1999; Ghosh, 2001; Chamarbagwala, 2006; Shu et al., 2007; Ding et al., 2009; Rani and Unni, 2009; Siddiqui, 2009). Much of the beneficial impact of freer trade on female employment has been concentrated in the exporting manufacturing sector in developing countries (particularly in textiles and leather) favoring predominantly unskilled women (see Standing, 1999; Özler, 2001; Kabeer and Mahmud, 2004; Chamarbagawala, 2006; Siddiqui, 2009). At the same time, import penetration from non-OECD countries has resulted in extensive job losses in the textiles, apparel and leather industries in OECD countries, which particularly affected female employees (Kucera and Milberg, 2000; Kucera, 2001).

Table 2. Studies of the effect of trade on employment 


\begin{tabular}{|c|c|c|c|c|c|c|}
\hline Study & $\begin{array}{l}\text { Direction } \\
\text { of effect }\end{array}$ & $\begin{array}{l}\text { Measure of } \\
\text { Employment }\end{array}$ & $\begin{array}{c}\text { Measure of } \\
\text { Openness }\end{array}$ & Sector & $\begin{array}{l}\text { Geographical } \\
\text { Focus }\end{array}$ & $\begin{array}{l}\text { Type of } \\
\text { Study }\end{array}$ \\
\hline $\begin{array}{l}\text { Ahmed and } \\
\text { Bukhari (2006) }\end{array}$ & $\alpha_{1}>0$ & Relative Female-Male & $\begin{array}{l}\text { Imports and Exports } \\
\text { in GDP }\end{array}$ & Overall Economy & $\begin{array}{l}\text { Pakistan, } \\
1973-2005\end{array}$ & $\mathrm{EC}, \mathrm{NA}$ \\
\hline $\begin{array}{l}\text { Barrientos et al. } \\
\text { (2004) }\end{array}$ & $\alpha_{1}>0$ & Female & $\begin{array}{l}\text { Adoption of Export- } \\
\text { Led Strategies }\end{array}$ & $\begin{array}{l}\text { Manufacturing } \\
\text { HV Agriculture }\end{array}$ & NGF & LR \\
\hline $\begin{array}{l}\text { Chamarbagwala } \\
\text { (2006) }\end{array}$ & $\begin{array}{c}\alpha_{2(\mathrm{P})}>0 \\
\alpha_{2(\mathrm{P})}<0 \\
\alpha_{1}<0 \\
\alpha_{2(\mathrm{P})}<0 \\
\alpha_{2(\mathrm{P})}>0 \\
\alpha_{1}<0\end{array}$ & $\begin{array}{l}\text { Female (Unskilled) } \\
\text { Female (Skilled) } \\
\text { Relative Female-Male } \\
\text { Female (Unskilled) } \\
\text { Female (Skilled) } \\
\text { Relative Female-Male }\end{array}$ & $\begin{array}{l}\text { Net Exports in } \\
\text { Output per Industry }\end{array}$ & $\begin{array}{c}\text { Manufacturing } \\
\text { Services }\end{array}$ & $\begin{array}{l}\text { India, } \\
\text { 1983-2000 }\end{array}$ & $\begin{array}{c}\text { EC, WS, } \\
\text { DS, } \\
\text { IOFA }\end{array}$ \\
\hline $\begin{array}{l}\text { Ding et al. } \\
\text { (2009) }\end{array}$ & $\alpha_{1}<0$ & $\begin{array}{c}\text { Relative Female-Male } \\
\text { (married women, } \\
\text { men) }\end{array}$ & $\begin{array}{l}\text { Adoption of Export- } \\
\text { Led Strategies }\end{array}$ & Cross-Sector & $\begin{array}{l}\text { China, } \\
\text { 1995-2002 }\end{array}$ & DS, HS \\
\hline $\begin{array}{l}\text { Ederington et al. } \\
\text { (2009) }\end{array}$ & $\begin{array}{c}\alpha_{1}>0 \\
\alpha_{2(\mathrm{P})}<0\end{array}$ & $\begin{array}{l}\text { Relative Female-Male } \\
\text { (Overall) } \\
\text { Relative Female-Male } \\
\text { (Capital-Intensive } \\
\text { Sectors) }\end{array}$ & $\begin{array}{l}\text { Exports in Output per } \\
\text { Industry }\end{array}$ & Manufacturing & $\begin{array}{l}\text { Colombia, } \\
\text { 1984-1991 }\end{array}$ & $\mathrm{EC}, \mathrm{NA}$ \\
\hline Fontana (2007) & $\begin{array}{l}\alpha_{2(\mathrm{P})}>0 \\
\alpha_{2(\mathrm{P})}<0 \\
\alpha_{2(\mathrm{P})}>0 \\
\alpha_{2(\mathrm{P})}>0 \\
\alpha_{2(\mathrm{P})}<0 \\
\alpha_{2(\mathrm{P})}<0\end{array}$ & $\begin{array}{c}\text { Female Overall (B), } \\
\text { Female Garments (B), } \\
\text { Female } \\
\text { Manufacturing (B) } \\
\text { Relative Female-Male } \\
\text { (B) } \\
\text { Female Overall (Z), } \\
\text { Female Mining (Z) } \\
\text { Female } \\
\text { Manufacturing (Z) } \\
\text { Relative Female-Male } \\
\text { (Z) }\end{array}$ & $\begin{array}{l}\text { Abolition of Tariffs } \\
\text { and Depreciation of } \\
\text { Exchange Rate }\end{array}$ & Cross-Sector & $\begin{array}{l}\text { Bangladesh } \\
\text { (B), 1994; } \\
\text { Zambia (Z), } \\
1995\end{array}$ & CGE \\
\hline Ghiara (1999) & $\alpha_{1}<0$ & Female & $\begin{array}{l}\text { Adoption of Export- } \\
\text { Led Strategies }\end{array}$ & Trade Sectors & $\begin{array}{c}\text { Mexico, } \\
1987-1993\end{array}$ & $\begin{array}{c}\text { EC, WS- } \\
\text { HS }\end{array}$ \\
\hline $\begin{array}{l}\text { Kabeer and } \\
\text { Mahmud (2004) }\end{array}$ & $\alpha_{1}>0$ & Female & $\begin{array}{l}\text { Adoption of Export- } \\
\text { Led Strategies }\end{array}$ & $\begin{array}{l}\text { Manufacturing } \\
\text { (Textiles) }\end{array}$ & $\begin{array}{l}\text { Bangladesh, } \\
\text { 1980s-2001 }\end{array}$ & DS, HS \\
\hline Kongar (2007) & $\begin{array}{c}\alpha_{1}<0 \\
\alpha_{2(\mathrm{P})}<0 \\
\alpha_{2(\mathrm{P})}>0 \\
\alpha_{1}<0\end{array}$ & $\begin{array}{c}\text { Female (overall) } \\
\text { Female (Unskilled) } \\
\text { Female (Skilled) } \\
\text { Relative Female-Male }\end{array}$ & $\begin{array}{l}\text { Imports in Output per } \\
\text { Industry }\end{array}$ & Manufacturing & $\begin{array}{c}\text { US, } \\
1976-1993\end{array}$ & $\mathrm{EC}, \mathrm{NA}$ \\
\hline $\begin{array}{l}\text { Kucera and } \\
\text { Milberg (2000) }\end{array}$ & $\alpha_{1}<0$ & Relative Female-Male & $\begin{array}{l}\text { Increase in Net } \\
\text { Exports }\end{array}$ & $\begin{array}{l}\text { Manufacturing } \\
\text { (Textiles) }\end{array}$ & $\begin{array}{c}\text { OECD, } \\
1978-1995\end{array}$ & IOFA/DS \\
\hline Özler (2001) & $\begin{array}{c}\alpha_{1}>0 \\
\alpha_{2(\mathrm{P})}>0 \\
\alpha_{2(\mathrm{P})}<0\end{array}$ & $\begin{array}{c}\text { Relative Female-Male } \\
\text { Relative Female-Male } \\
\text { (Unskilled) } \\
\text { Relative Female-Male } \\
\text { (Capital-Intensive } \\
\text { Sectors) }\end{array}$ & $\begin{array}{l}\text { Exports in Output per } \\
\text { Industry }\end{array}$ & Manufacturing & $\begin{array}{c}\text { Turkey, } \\
1983-1985\end{array}$ & $\mathrm{EC}, \mathrm{NA}$ \\
\hline Özler (2007) & $\begin{array}{c}\alpha_{1}>0 \\
\alpha_{2(\mathrm{P})}>0\end{array}$ & $\begin{array}{c}\text { Relative Female-Male } \\
\text { Relative Female-Male } \\
\text { (Skilled) }\end{array}$ & $\begin{array}{l}\text { Adoption of Export- } \\
\text { Led Strategies }\end{array}$ & Manufacturing & $\begin{array}{l}\text { Turkey, } \\
\text { 1986-1996 }\end{array}$ & DS \\
\hline $\begin{array}{l}\text { Rani and Unni } \\
(2009)\end{array}$ & $\alpha_{1}<0$ & Relative Female-Male & $\begin{array}{l}\text { Adoption of Export- } \\
\text { Led Strategies }\end{array}$ & $\begin{array}{l}\text { Manufacturing } \\
\text { (Home-based } \\
\text { Subcontracting) }\end{array}$ & $\begin{array}{c}\text { India, } \\
1994-1995, \\
2000-2001\end{array}$ & EC, WS \\
\hline Siddiqui (2009) & $\alpha_{2(\mathrm{P})}>0$ & Female (Unskilled) & Reduction of Tariffs & Cross-Sector & Pakistan, & CGE \\
\hline
\end{tabular}




\begin{tabular}{|c|c|c|c|c|c|c|}
\hline & $\begin{array}{l}\alpha_{1}<0 \\
\alpha_{1}<0\end{array}$ & $\begin{array}{c}\text { Female (Overall) } \\
\text { Relative Female-Male }\end{array}$ & & & 1993 & \\
\hline Standing (1999) & $\begin{array}{l}\alpha_{1}>0 \\
\alpha_{1}>0\end{array}$ & $\begin{array}{c}\text { Female } \\
\text { Relative Female-Male }\end{array}$ & $\begin{array}{l}\text { Adoption of Export- } \\
\text { Led Strategies }\end{array}$ & $\begin{array}{l}\text { Manufacturing } \\
\text { (Textiles) }\end{array}$ & $\begin{array}{c}\text { D1, D2: NGF, } \\
\text { 1975-1995 }\end{array}$ & DS \\
\hline Tucker (2007) & $\alpha_{1}<0$ & Relative Female-Male & Expansion of Sector & Services (Tourism) & $\begin{array}{l}\text { Turkey, } \\
1995-2005\end{array}$ & ES \\
\hline $\begin{array}{l}\text { von Braun et al. } \\
\text { (1994) }\end{array}$ & $\alpha_{1}<0$ & Relative Female-Male & $\begin{array}{l}\text { Commercialisation, } \\
\text { New Technologies }\end{array}$ & Agriculture & $\begin{array}{c}\text { The Gambia, } \\
\text { 1980s }\end{array}$ & $\begin{array}{c}\text { CS, EC, } \\
\text { HS }\end{array}$ \\
\hline Wilson (2008) & $\alpha_{1}<0$ & Relative Female-Male & Expansion of Sector & Services (Tourism) & $\begin{array}{l}\text { Mexico } \\
2005\end{array}$ & DS \\
\hline Wold (1997) & $\alpha_{1}<0$ & Relative Female-Male & $\begin{array}{l}\text { Adoption of Export- } \\
\text { Led Strategies }\end{array}$ & Agriculture & Zambia, 1990s & CS/DS \\
\hline
\end{tabular}

Abbreviations: CGE: Computer General Equilibrium Model, CS: Case-Study, D1: Developing Countries, D2: Developed Countries, DS: Descriptive Statistics, EC: Econometrics Analysis, ES: Ethnographic Study, HS: Household Survey, HV: High-Value, IOFA: Input-Output Factor Analysis, LR: Literature Review, NA: National Accounts, NGF: No Geographic Focus, WS: Worker Survey

Some studies suggest that while most trade-induced employment opportunities for women arise in manufacturing, such opportunities for employment in traditional agriculture tend to be relatively rare $^{7}$. First, women are more likely than men to be small-scale farmers, and therefore more constrained in expanding production as well as more vulnerable to price shocks (Garcia, 2005; Fontana, 2007). In Morocco, for instance, the average size of land holdings of men is about a hectare, while that of women about half a hectare (FAO, 2003). Second, women are more restricted than men in their access to credit and technological inputs, such as improved seeds, fertilisers and pesticides, and are therefore less able to take advantage of new market opportunities in non-traditional agriculture that international trade gives rise to. For the same reasons, when traditionally female-intensive crops become commercialised, men may enter and take over the sector (assisted by their relatively easier access to credit), as has happened with groundnuts in Zambia (Wold, 1997) and rice in the Gambia (van Braun, 1994).

Some recent studies have concentrated on the role of trade in stimulating female employment (both in absolute terms, as well as relative to men) in the services sector and then in the rapidly expanding ICT (Information and Communication Technologies) sector in particular; see Gurumurthy (2004) and Prasad and Sreedevi (2007). The employment gains for both sexes are geographically concentrated (and are found particularly in India, Mexico, Jamaica and the Philippines), and often substandard health and safety conditions at work are reported (Pearson and Mitter, 1993; Howcroft and Richardson, 2008). There is also ample evidence of a 'digital divide' within the ICT sector (see Patel and Parmentier, 2005; Wajcman and 
1

2

3

4

5

6

7

8

9

10

11

12

13

14

15

16

17

18

19

20

21

22

23

24

25

26

27

28

29

30

31

32

33

34

35

36

37

38

39

40

41

42

43

44

45

46

47

48

49

50

51

52

53

54

55

56

57

58

59

60

Lobb, 2007), which refers to occupational segregation by gender that has women performing tasks for which relatively few skills are required (for example, data processing) and men dominating the better-paid high-skilled slots (for example, programming). The recent rapid expansion of the tourism industry has offered employment opportunities for both the female and male population (Sinclair, 1999; Wilson, 2008), typically with relatively little gender bias, unless in countries with strong cultural norms against females serving strangers ${ }^{8}$ as well as in the sex services sector, where employment is not always voluntary and carries health risks particularly for women (Kempadoo, 1999, 2004; Clancy, 2002; Cabezas, 2009). Fertility (or reproductive) tourism has also been on the rise, with commercial surrogacy in particular often denounced as an exploitative practice against poorer women in developing countries (see Donchin, 2010).

Trade expansion may thus be associated both with positive and negative effects on women's employment opportunities and livelihoods, which may vary greatly by sector. The net effect of trade on female employment in any given country will naturally depend on which effects dominate ${ }^{9}$. 


\section{CONCLUding REMARKS}

There are multiple ways in which trade and gender income inequities are linked through the labour market, which we have attempted to summarise in this paper. While most studies suggest that trade liberalisation and expansion are not gender neutral, there is no consensus on the size and sign of effects. However, on balance the evidence for developing countries points to an overall beneficial impact of trade expansion on female employment, both relative to male employment and in absolute terms, although largely concentrated in unskilled manufacturing. By contrast, the bulk of the evidence suggests a widening gender wage gap as a result of freer trade. Furthermore, existing gender inequality in labour markets codetermines where a country's comparative advantage lies and thus shapes its export strategies. East Asia's growth strategy provides the most powerful illustration.

Trade liberalisation alters the relative and absolute size of productive sectors, and thereby reinforces certain inherent characteristics of the labour market and the overall structure of the economy and accordingly reinforces or weakens embedded patterns of gender inequality. There is a need to deepen our understanding of the functioning and dynamics of the labour market, in order to better explain the resulting pattern of gendered differences in wages, employment, and income. Precise knowledge of the wage elasticities of labour supply and demand for men and women separately, as well as the degree of substitutability of male and female labour, would provide a firmer handle on understanding the key gender-trade causal mechanisms (these are often provided only for developed economies where labour statistics are widely available, see Evers et al., 2008). Estimating these is demanding on the data, though, since such parameters are likely to be both country and sector specific. Nevertheless, they would aid our understanding of gendered labour supply and demand decisions, and how the two jointly explain gendered labour market segregation, which trade in certain occasions reinforces and in others weakens, as illustrated throughout this paper. 
A further remark is that a focus on gender - how trade-induced shifts interact with the socially constructed roles of men and women - goes beyond a focus on women (a common limitation in the literature). Many studies focus on the impact of trade expansion on female employment and earnings, neglecting the effect of trade on male employment patterns, and its overall impact at the household level. As Standing (1999) points out, the increased feminisation of many manufacturing sectors in particular (electronics, textiles, garments) corresponds not only with newly created employment opportunities for women in such sectors but also with females substituting for males in existing jobs. This suggests the importance of recognising that any beneficial impacts of trade on female employment and earnings may be simply counterbalanced by decreases in those of males, and of investigating the net effect on income at the household level.

${ }^{1}$ Heterodox trade theories, on the other hand, critique the Heckscher-Ohlin model and its conclusions by emphasising the role of absolute (rather than comparative) advantage in determining trade flows and gender inequalities (Elson et al., 2007).

${ }^{2}$ In a recent paper, though, Neumayer and de Soysa (2007) suggest that trade expansion itself may positively influence the overall protection provided to women's economic rights. A measure of economic rights is used that extends beyond wage differentials and employment to capture legal and institutional aspects, such as equality in promotion practices, protection against discrimination at work, protection from sexual harassment and the right to work in male-dominated professions (such as the military and police force). Moreover, the measure does not only capture the availability of legal protection but also its enforceability. A doubling of the share of exports and imports in GDP would translate in an improvement by approximately one unit in the 0-4 index of female economic rights (Neumayer and de Soysa, 2007).

${ }^{3}$ In order to capture such gendered differences in access to production factors, the Gender, Institutions and Development Database of the Organisation for Economic Co-operation and Development (OECD, 2009) constructs a 0 to 1 index of women's access to land, bank loans and other forms of property, where 0 indicates full access to resources. Women's access to resources is especially restricted in African and Middle Eastern Countries, where the index is well above 0.5 . This contrasts dramatically with women's access to resources in developed countries, where the index typically equals 0 .

${ }^{4}$ In rural areas in Mexico and Tanzania, for instance, husbands often forbid their wives to seek employment outside their households (see Willis, 1993 and Kabeer, 1996 respectively). 
${ }^{5}$ It is worth noticing that there is often a widening wage gap also across women; for example, between skilled and unskilled women in formal employment in Mexico (Ghiara, 1999).

${ }^{6}$ While state enterprises generally supported gender equality in wages, there is evidence that suggests that in the private sector female wages are more suppressed. Using the 1992 Chinese Labour Market Project data, Maurer-Fazio and Hughes (2002) find that the proportion of the gender wage gap that remains unexplained after controlling for gender differences in productivity is 47.4 per cent amongst private joint-venture firms and less than half, 23.0 per cent, among state enterprises.

${ }^{7}$ High-value non-traditional agriculture (for example, horticulture and floriculture) has on the other hand stimulated female labour employment to a certain extent - although often in the form of seasonal 'buffer' employment, with men holding the relatively more secure positions (Barrientos et al., 2004).

${ }^{8}$ For example, male employment tends to benefit more from the expansion of the tourism industry in predominantly Muslim nations (see Tucker, 2007).

${ }^{9}$ The relative abundance of most African and Asian nations in land and unskilled labour respectively, explains to a large extent why Africa has specialised more in agricultural commodities, whereas Asia in light manufacturing that depends on manual labour (Wood, 1994). Women tend to constitute a disproportionately large share of the unskilled labour force in most developing countries, while men unevenly dominate in terms of land ownership. This disparity in trade specialisation explains to some extent why trade expansion has benefited women to a larger extent in Asia (as unskilled workers, often employed in the garment and textile industry) rather than in Africa, where limited female access to land as well as other factors has hampered their involvement in agricultural exporting activities. 


\section{References}

Ahmed, N. and Bukhari, S.K.H. (2006) Gender inequality and trade liberalization: A case study of Pakistan. MPRA Paper 16252. University Library of Munich, Germany.

Anderson, E. (2005) Openness and inequality in developing countries: A review of theory and recent evidence. World Development 33(7), pp. 1045-1063.

Anker, R. (1997) Theories of occupational segregation by sex: An overview. International Labour Review 116(3), pp.315-339.

Arizpe, L. and Aranda, J. (1981) The "comparative advantages" of women's disadvantages: Women workers in the strawberry export agribusiness in Mexico. Signs 7(2), pp. 453-473.

Balakrishnan, R. (2002) The Hidden Assembly Line: Gender Dynamics in Subcontracted Work in a Global Economy (Bloomfield CN: Kumarian Press).

Baliamoune-Lutz, M. (2006) Globalisation and gender inequality: Is Africa different? Journal of African Economies 16(2), pp. 301-348.

Barrientos, S., Kabeer, N. and Hossain, N. (2004) The gender dimensions of the globalization of production. Working Paper No.17, Policy Integration Department, World Commission on the Social Dimension of Globalization, International Labour Office, Geneva.

Becker, G. (1971) The Economics of Discrimination (Chicago: Chicago University Press).

Berik, G. (2007) Mature export-led growth and gender wage inequality in Taiwan, in I. van Steveren, D. Elson, C. Grown and N. Çağatay (eds) The Feminist Economics of Trade (Chippenham: Routledge), pp. 141-163.

Berik, G., Rodgers, Y. and Zveglich, J.E. (2004) International trade and gender wage discrimination: Evidence from East Asia. Review of Development Economics 8(2), pp. 237254.

Bhaskar, V., Manning, A. and To, T. (2002) Oligopsony and monopsonistic competition in labor markets. Journal of Economic Perspectives 16(2), pp.155-174.

Black, D.A. (1995) Discrimination in an equilibrium search model. Journal of Labor Economics 13(2), pp.309-33.

Black, S. and Brainerd, E. (2004). Importing equality? The impact of globalization on gender discrimination. Industrial and Labor Relations Review 57(4), pp. 540-559.

Braunstein, E. and Brenner, M. (2007) Foreign direct investment and gendered wages in urban China. Feminist Economics 13(3-4), pp.213-237.

Busse, M. and Nunnenkamp, N. (2009) Gender disparity in education and the international competition for foreign direct investment. Feminist Economics 15(3), pp. 61-90. 
Cabezas, A.L. (2009) Economies of Desire: Sex Tourism in Cuba and the Dominican Republic (Philadelphia, PA: Temple University Press).

Çağatay, N. (2001) Trade, Gender and Poverty (New York: UNDP).

Çağatay, N. (2003) Gender budgets and beyond: Feminist fiscal policy in the context of globalisation. Gender and Development 11(1), pp. 15-24.

Carr, M, Chen, M. and Tate, J. (2000) Globalization and home-based workers. Feminist Economics 6(3), pp. 123-142.

Chamarbagwala, R. (2006) Economic liberalization and wage inequality in India. World Development 34(12), pp.1997-2015.

Chant, S. (1995) Gender and export manufacturing in the Philippines: Continuity or change in female employment? The case of the Mactan Export Processing Zone. Gender, Place and Culture 2(2), pp. 147-176.

Clancy, M. (2002) The globalization of sex tourism in Cuba: A commodity chains approach. Studies in Comparative International Development 36(4), pp.63-88.

Davidson, C. and Matusz, S., (2010) International Trade with Equilibrium Unemployment (Princeton, NJ: Princeton University Press).

Davidson, C. Martin, L. and Matusz, S. (1988) The structure of simple general equilibrium models with frictional unemployment. Journal of Political Economy 96(6), pp. 1267-1293.

Davidson, C. Martin, L. and Matusz, S., (1999) Trade and search generated unemployment. Journal of International Economics 48(2), pp. 271-299.

Ding, S., Dong, X. and Li, S. (2009) Women's employment and family income inequality during China's economic transition. Feminist Economics 15(3), pp.163-190.

Donchin, A. (2010) Reproductive tourism and the quest for global gender justice. Bioethics 24(7), pp. 323-332.

Ederington, J., Minier, J. and Troske, K.R. (2009) Where the girls are: Trade and labor market segregation in Colombia. IZA Discussion Paper No.4131, IZA, Bonn.

Elson, D. (1999) Labor markets as gendered institutions: equality, efficiency and empowerment issues. World Development 27(3), pp. 611-627.

Elson, D. and Evers, B. (1996) Gender aware country economic reports: Uganda, GENECON Unit Working Paper 2, University of Manchester.

Elson, D., Grown, C. and Çağatay, N. (2007) Mainstream, heterodox, and feminist trade theory, in I. van Steveren, D. Elson, C. Grown and N. Çăgatay (eds) The Feminist Economics of Trade (Chippenham: Routledge), pp. 33-52.

Evers, M., de Mooij, R. and van Vuuren, D., (2008) The wage elasticity of labour supply: A synthesis of empirical evidence. De Economist 156 (1), pp. 25-43.

FAO (2003) Rural women: Key to food security. Plan of action: Gender and Development, Rome, Food and Agriculture Organization. 
Fleck, S. (2001) A gender perspective on maquila employment and wages in Mexico, in E. Katz and M. Correia, (eds) The Economics of Gender in Mexico (Washington DC: The World Bank), pp. 133-169.

Fontana, M. (2003) The gender effects of trade liberalization in developing countries. Discussion Papers in Economics No 101, University of Sussex.

Fontana, M. (2007) Modelling the effects of trade on women, at work and at home: Comparative perspectives, in I. van Steveren, D. Elson, C. Grown and N. Çağatay (eds) The Feminist Economics of Trade (Chippenham: Routledge), pp. 117-140.

Fussell, E. (2000) Making labor flexible: The recomposition of Tijuana's maquiladora female labor force. Feminist Economics 6(3), pp. 59-79.

Garcia, Z. (2005). Impact of agricultural trade on gender equity and the position of rural women in developing countries. Federico Caffe Centre Research Report 9/2005. Rome, FAO.

Ghiara, G. (1999) Impact of trade liberalisation on female wages in Mexico. Development Policy Review 17(2), pp. 171-190.

Ghosh, J. (2001) Globalisation, export-oriented employment for women and social policy: A case study of India. Report prepared for the UNRISD project on globalization, export-oriented employment for women and social policy (Geneva: UNRISD).

Glick, P. and Roubaud, F. (2006) Export processing zone expansion in Madagascar: What are the labour market and gender impacts? Journal of African Economies 15(4), pp. 722-756.

Gray, M. and Kittilson, M.C. and Sandholtz, W. (2006) Women and globalization: A study of 180 countries, 1975-2000. International Organization 60(2), pp. 293-333.

Grown, C. (2006) What gender inequality advocates should know about taxation. AWID Occasional Paper: Association for Women's Rights in Development, Toronto.

Gurumurthy, A. (2004) Gender and ICTs: Overview report. BRIDGE Development-Gender Report (Brighton, UK: Institute for Development Studies).

Howcroft, D. and Richardson, H. (2008) Gender matters in the global outsourcing of service work. New Technology, Work and Employment 23(1-2), pp.44-60.

Joekes, S. (1999) Gender, property rights and trade: constraints to African growth, in K. King and S. McGrath (eds) Enterprise in Africa: Between Poverty and Growth (London: Intermediate Technology Publications), pp. 71-82.

Kabeer, N. (2000) The Power to Choose: Bangladeshi Women and Labour Market Decisions in London and Dhaka (London: Verso).

Kabeer, N. and Mahmud, S. (2004) Globalization, gender and poverty: Bangladeshi women workers in export and local markets. Journal of International Development 16(1), pp. 93-109.

Kempadoo, K. (1999) Sun, Sex, and Gold: Tourism and Sex Work in the Caribbean (Oxford, UK: Rowman and Littlefield Publishers). 
Kempadoo, K. (2004) Sexing the Caribbean: Gender, Race and Sexual Labor (Abingdon, UK: Routledge).

Kennedy, E. (1994) Effects of sugarcane production in Southwestern Kenya on income and nutrition, in J. von Braun and E. Kennedy (eds) Agricultural Commercialisation, Economic Development and Nutrition (Baltimore: Johns Hopkins University Press), pp. 252-263.

Kongar, E., (2007) Importing equality or exporting jobs? Competition and gender wage and employment differentials in US manufacturing, in I. van Steveren, D. Elson, C. Grown and N. Çağatay (eds) The Feminist Economics of Trade (Chippenham: Routledge), pp. 215-236.

Kucera, D. and Milberg, W. (2000) Gender segregation and gender bias in manufacturing trade expansion: Revisiting the "Wood Asymmetry". World Development 28(7), pp. 1191-1210.

Kucera, D. (2001) Gender, Growth, and Trade: The Miracle Economies of the Postwar Years (London, Routledge).

Lazcano, O. (2003) Gender stereotype-like indicators of work organization in factories of the Puebla and Tlaxcala states in Mexico. International Journal of Industrial Economics 31(3), pp. 185-194.

Manning, A. (2003) Monopsony in Motion: Imperfect Competition in Labor Markets (Princeton, NJ: Princenton University Press).

Maurer-Fazio, M. and Hughes, J. (2002) The effects of market liberalization on the relative earnings of Chinese women. Journal of Comparative Economics 30(4), pp. 709-731.

Menon, N. and Rodgers, Y. (2009) International trade and the gender wage gap: New evidence from India's manufacturing sector. World Development 37(5), pp. 965-981.

Neumayer, E. and de Soysa, I. (2007) Globalization, women's economic rights and forced labor. The World Economy 30(10), 1510-1535.

Newman, C. (2002) Gender, time use, and change: Impact of the cut flower industry in Ecuador. The World Bank Economic Review 16(3), pp. 375-396.

Nicita, A. and Razzaz, S. (2003) Who benefits and how much? How gender affects welfare impacts of a booming textile industry. Policy Research Working Paper Series 3029, The World Bank.

OECD (2009) Gender, Institutions and Development Database (Paris, France). Accessed at http://www.oecd.org/document/16/0,3343,en_2649_33731_39323280_1_1_1_1,00.html.

Oostendorp, R.H. (2009) Globalization and the gender wage gap. The World Bank Economic Review 23(1), pp. 141-161.

Özler, Ş. (2000) Export orientation and female share of employment: Evidence from Turkey. World Development 28(7), pp.1239-1248.

Özler, Ş. (2007) Export-led industrialization and gender differences in job creation and destruction: Micro evidence from the Turkish manufacturing sector, in I. van Steveren, D. 
Elson, C. Grown and N. Çă̆atay (eds) The Feminist Economics of Trade (Chippenham: Routledge), pp. 164-184.

Palmer, I. (1995) Public finance from a gender perspective. World Development 23(11), pp. 1981-1986.

Patel, P. and Parmentier, M.J.C. (2005) The persistence of traditional gender roles in the Information Technology sector: A study of female engineers in India. Information Technology and International Development 2(3), pp.29-46.

Paul-Majumder, P. and Begum, A. (2000) The gender imbalances in the export oriented garment industry in Bangladesh. Policy Research Report on Gender and Development, Working Paper Series No 12, The World Bank.

Pearson, R. and Mitter, S. (1993) Employment and working conditions of low-skilled information-processing workers in less-developed countries. International Labor Review 132(1), pp. 49-64.

Peralta A., Mukherjee A. and Iorio, M.R. (2006) Globalization, Trade-Finance Linkages and Gender: Implications to Asian Women. International Gender and trade Network-Asia Report (IGTN-Asia).

Prasad, P.N. and Sreedevi, V. (2007). Economic empowerment of women through information technology. Journal if International Women's Studies 8(4), pp. 107-120.

Rani, U. and Unni, J. (2009) Do economic reforms influence home-based work? Evidence from India. Feminist Economics 15(3), pp.191-225.

Rao J.M. (2001) Globalization and the fiscal autonomy of the State. Political Economy Research Institute, University of Massachusetts Amherst, Working Paper No 25.

Rodrik, D. (2000) Institutions for high-quality growth: What they are and how to acquire them. Studies in Comparative International Development 35(3), pp. 3-31.

Santos, L.D. and Varejão (2007) Employment, pay and discrimination in the tourism industry. Tourism Economics 13(2), pp.225-240.

Sayeed, A. and Balakrishnan, R. (2002). Why do firms disintegrate? Towards an understanding of the firm level decision to sub-contract and its impact on labour. CEPA Working Paper 2002-12.

Seguino, S. (1997) Gender wage inequality and export-led growth in South Korea. Journal of Development Studies 34(3), pp.102-137.

Seguino, S. (2000a) Accounting for gender in Asian economic growth. Feminist Economics 6(3), pp. 27-58.

Seguino, S. (2000b) Gender inequality and economic growth: A cross-country analysis. World Development 28(7), pp. 1211-1230.

Seguino, S. (2007a) Is more mobility good? Mobile capital and the low wage-low productivity trap. Structural Change and Economic Dynamics 18(1), pp. 27-51. 
Seguino, S. (2007b) Plus ça change? Evidence on global trends in gender norms and stereotypes. Feminist Economics 13(2), pp. 1-28.

Siddiqui, R. (2009) Modelling gender effects of Pakistan's trade liberalization. Feminist Economics 15(3), pp.287-321.

Sinclair, M.T. (1997) Gender, Work and Tourism (London, UK: Routledge)

Standing, G. (1999) Global feminization through flexible labor: A theme revisited. World Development 27(3), pp. 583-602.

Tejani, S. And Milberg, W. (2010) Global defeminization? Industrial upgrading, occupational segmentation and manufacturing employment in middle-income countries. New York, Schwartz Center for Economic Policy Analysis Working Paper 2010-1.

Thrane, C. (2008) Earnings differentiation in the tourism industry: Gender, human capital and socio-demographic effects. Tourism Management 29(3), pp. 514-524.

Tiano, S. (1994) Patriarchy on the Line: Gender, Labor, and Ideology in the Mexican Maquila Industry (Philadelphia: Temple University Press).

Tran-Nyugen, A.-N. and Bevigilia Zampetti, A. (2004). Trade and Gender: Opportunities and Challenges for Developing Countries (New York and Geneva: UNCTAD).

Tucker, H. (2007) Undoing shame: Tourism and women's work in Turkey. Journal of Tourism and Cultural Change 5(2), pp. 87-105.

von Braun, J., John, K. and Puetz, D. (1994) Nutritional effects of commercialisation of a woman's crop: irrigated rice, in J. von Braun and E. Kennedy (eds) Agricultural Commercialisation, Economic Development and Nutrition (Baltimore: Johns Hopkins University Press), pp. 343363.

Wajcman, J. and Lobb, L.A.B. (2007) The gender relations of software work in Vietnam. Technology and Development 11(1), pp.1-26.

Willis, K. (1993) Women's work and social network use in Oaxaca City, Mexico. Bulletin of Latin American Research 12(1), pp. 65-82.

Waldfogel, J. (1998) Understanding the 'family gap' in pay for women with children. Journal of Economic Perspectives 12(1), pp.137-156.

Wilson, T.D. (2008) Economic and social impacts of tourism in Mexico. Latin American Perspectives 35(3), pp. 37-52.

Wold, B.K. (1997) Supply response in a gender-perspective: The case of structural adjustment in Zambia, Oslo: Statistics Norway.

Wood, A. (1994) North-South Trade, Employment and Inequalities: Changing Fortunes in a Skill-Driven World (Oxford: Oxford University Press).

Insert Appendix 


\section{APPENDIX: GENDER AND TRADE: IMPACTS BEYOND INCOME}

There has been considerable attention in the literature on the impact of trade expansion on aspects of gender inequality other than the ones focused on above, so extending beyond income, the gender wage gap and differences in employment across the sexes. Here we briefly discuss some of the evidence on the gendered impact of trade on health, nutrition and food security, the provision of public services and social norms, acknowledging though that each of these themes would merit a separate literature review in order to do justice to the vast research that has been undertaken in these fields, and we restrict ourselves to a concise summary of the key evidence.

\section{Health Impacts}

Increased employment opportunities for women (often as a result of trade expansion) imply that additional income accrues to the household, allowing hence a potentially broader array of consumption goods to be purchased. Kennedy (1994) provides some gender-specific evidence on the impact of female employment in the commercialised agricultural sector in Guatemala and finds, though, that while children's health improves by the additional household purchasing power brought about by female income, women themselves experience weight loss and poorer health. Numerous studies place particular emphasis on the precarious nature of employment and substandard working conditions that employees and women in particular face in expanding exporting sectors (see Pearson and Mitter, 1993; Chant, 1995; PaulMajumder and Begum, 2000; Lazcano, 2003; Barrientos et al., 2004; Glick and Roubaud, 2006). Although most evidence points to a common pattern of adverse working conditions across most exportoriented sectors in developing countries, the result has to be treated with caution in order to derive any comparative insights. There is very little evidence that working conditions appear to be of better quality in the non-export sector, and therefore an expansion of trading activities may simply reinforce a general pattern of widespread economy-wide poor working conditions. 


\section{Food Security/Nutrition}

Trade expansion may also negatively impact on food security, particularly for those vulnerable individuals and households with low purchasing power. Trade affects the relative prices of goods, and often results in an increase of domestic prices of agricultural commodities when exported. This places a disproportionate burden on poor households with weak purchasing power. When women direct their work effort away from home-based and consumed agriculture towards the formal economy, much of their income earned may simply be dissipated in purchases of food previously produced at home (Elson and Evers, 1996). Similarly an increase in income and consequent food consumption may not fully substitute for a decline in breastfeeding and worsening childcare practices, which may come about as a result of an extended length of women's working day and unfavourable strong cultural and social norms that limit the reallocation of household tasks to husbands (Elson and Evers, 1996).

\section{Provision of Public Services}

An additional impact, that has received little attention so far in the literature, is the effect of lower trade barriers (such as import quotas, but mainly tariffs) on public expenditure (Elson et al., 2007). The shift from tariffs to Valued Added Taxes (VAT) does not usually compensate for the loss in public revenues and results in reductions in the supply of public services (such as health and education) and/or subsidies on basic commodities (such as electricity and water). The gradual elimination of tariffs between 1970 and 1990 is found, for instance, to be associated with a general pattern of reduced social expenditure (particularly spending on education) as a share of GDP for the same period for the least developed economies (Rao, 2001). Rao (2001) claims that a \$1 decline in trade-tax revenues results on average in a decrease of public expenditure on capital formation and human capital by $\$ 0.37$. Simultaneously, the imposition of a VAT increases prices of basic commodities and services consumed by the household. Although the effect is not gender specific and affects the household as a whole, it is usually women who are in charge of the purchase of these basic commodities (such as food) whose prices rise (Palmer, 1995; Grown, 2006; Peralta et al., 2006). Women, with primary responsibility for household welfare, hence, 
often need to counterbalance price increases in basic commodities by extending their work time and effort. Furthermore, removals of state support, such as public services and subsidies for inputs and credit, often marginalise poor producers, many of them women, and deprive them of access to essential assets to commence production (Athill et al., 2007). Furthermore, cutbacks in the public sector may disproportionately affect female employment to the extent that the public sector is characterized by lower gender segregation (Çağatay, 2003). More broadly, women may simply suffer disproportionately from an increase in indirect taxes, and/or reduction in public spending, since they are often more vulnerable to income poverty than men (Çağatay, 2003). These effects can potentially be substantial but further research would need to quantify the impacts and verify whether they disproportionately affect women.

\section{Social Norms/Empowerment}

On the other hand, the arrival of trade-related female employment opportunities (and subsequent income flows) has in many cases weakened norms that traditionally excluded women from formal productive activities and increased their intrahousehold bargaining position. In that respect, a number of studies suggest that waged women tend to experience, as a side effect of controlling their income, an increase in their bargaining power within the household (Arizpe and Aranda, 1981; Tiano, 1994; Chant, 1995; PaulMajumder and Begum, 2000; Kabeer, 2004). Increased female employment and control of own income, for instance, provide young women with the opportunity to delay marriage and childbirth. Paul-Majumder and Begum (2000) provide supportive evidence indicating that female workers in the garment industry in Bangladesh postpone on average both their age of marriage as well as first childbirth by approximately four years. Women's control of own income may also weaken traditional attitudes regarding the intrahousehold division of labour between productive and reproductive tasks. For instance, a recent study of the effect of female employment in the non-traditional agricultural exporting sector (NTAEs) in Ecuador on the intrahousehold time allocation (Newman, 2002) finds that women receive substantial help from their husbands for reproductive activities, especially when the latter are employed in the same sector. Seguino (2007b) also finds that female access to paid employment promotes gender-equitable norms 
across countries (for example, with respect to the gender division of labour and relative female power), making use of the World Values Survey dataset. In a broader context, the opportunity of female employees to earn their own income by engaging in expanding trading sectors has been related directly to an improvement in their self-esteem and social appreciation, and indirectly to a decrease in the incidence of forced labour and enhanced representation in parliament (see Gray et al., 2006; Neumayer and de Soysa, 2007). Nevertheless, this shift in attitudes towards gender is far from universal and in many cases existing norms prevail and women continue to receive little assistance from their husbands, other males in their extended families, NGOs or the state for reproductive tasks. 
Black and Brainerd (2004)

Braunstein and Brenner (2007)

Carr et al.

(2000)

Fleck (2001)

Fontana (2007)

Fussel (2000)

Ghiara (1999)

Glick and Roubaud (2006)

Kabeer and Mahmud (2004)

Kongar (2007)

Maurer-Fazio and Hughes

(2002)

Menon and

Rodgers (2009)

Nicita and Razzaz (2003)

Oostendorp (2009)

Paul-Majumder and Begum

Table 1. Studies of the effect of trade on wages

Measure of $\quad$ Sector Geographical Type of

\begin{tabular}{|c|c|c|c|c|c|}
\hline $\begin{array}{c}\text { Direction } \\
\text { of effect }\end{array}$ & Wages & $\begin{array}{c}\text { Measure of } \\
\text { Openness }\end{array}$ & Sector & $\begin{array}{c}\text { Geographical } \\
\text { Focus }\end{array}$ & $\begin{array}{l}\text { Type of } \\
\text { Study }\end{array}$ \\
\hline $\begin{array}{l}\alpha_{1}<0 \\
\alpha_{1}>0\end{array}$ & $\begin{array}{c}\text { Relative Female-Male } \\
\text { Discrimination } \\
\text { Component of Wage Gap }\end{array}$ & $\begin{array}{c}\text { Difference in Tariff } \\
\text { Levels and Quota } \\
\text { Rates }\end{array}$ & Manufacturing & $\begin{array}{l}\text { Mexico, } \\
\text { 1987-1993 }\end{array}$ & $\mathrm{EC}, \mathrm{WS}$ \\
\hline $\begin{array}{l}\alpha_{1}<0 \\
\alpha_{1}>0\end{array}$ & $\begin{array}{c}\text { Female } \\
\text { Relative Female-Male }\end{array}$ & $\begin{array}{l}\text { Exports in Output per } \\
\text { Industry }\end{array}$ & Manufacturing & $\begin{array}{c}\text { Taiwan, 1981- } \\
1996\end{array}$ & $\begin{array}{l}\text { EC, WS, } \\
\text { NA }\end{array}$ \\
\hline$\alpha_{1}<0$ & Relative Female-Male & $\begin{array}{l}\text { Imports in Output per } \\
\text { Industry (Taiwan) } \\
\text { Exports in Output per } \\
\text { Industry (South } \\
\text { Korea) }\end{array}$ & Manufacturing & $\begin{array}{l}\text { South Korea, } \\
\text { Taiwan, } \\
\text { 1981-1999 }\end{array}$ & $\begin{array}{l}\text { EC, WS, } \\
\text { NA }\end{array}$ \\
\hline
\end{tabular}

\begin{tabular}{|c|c|c|c|c|c|}
\hline$\alpha_{1}>0$ & Relative Female-Male & $\begin{array}{l}\text { Imports in Output per } \\
\text { Industry }\end{array}$ & Manufacturing & $\begin{array}{c}\text { US, } \\
1976-1993\end{array}$ & EC, NA \\
\hline$\alpha_{1}<0$ & Relative Female-Male & $\begin{array}{l}\text { FDI in Total } \\
\text { Investment }\end{array}$ & Cross-Sector & $\begin{array}{l}\text { China, } \\
2002\end{array}$ & $\begin{array}{c}\text { EC, HS, } \\
\text { NA }\end{array}$ \\
\hline$\alpha_{1}<0$ & $\begin{array}{c}\text { Female } \\
\text { Relative Female-Male }\end{array}$ & $\begin{array}{l}\text { Adoption of Export- } \\
\text { Led Strategies }\end{array}$ & $\begin{array}{l}\text { Informal (HB): } \\
\text { Garments, NTA }\end{array}$ & $\begin{array}{l}\text { NGF, } \\
1990 \mathrm{~s}\end{array}$ & LR \\
\hline$\alpha_{1}<0$ & Relative Female-Male & $\begin{array}{l}\text { Adoption of Export- } \\
\text { Led Strategies }\end{array}$ & $\begin{array}{l}\text { Manufacturing } \\
\text { (Maquilas) }\end{array}$ & $\begin{array}{l}\text { Mexico, } \\
\text { 1997-1998 }\end{array}$ & EC, HS \\
\hline $\begin{array}{l}\alpha_{2(\mathrm{P})}>0 \\
\alpha_{2(\mathrm{P})}>0\end{array}$ & $\begin{array}{l}\text { Female (Bangladesh) } \\
\text { Relative Female-Male }\end{array}$ & $\begin{array}{l}\text { Abolition of Tariffs } \\
\text { and Depreciation of }\end{array}$ & Cross-Sector & $\begin{array}{l}\text { Bangladesh } \\
\text { 1994, Zambia }\end{array}$ & CGE \\
\hline $\begin{array}{l}\alpha_{2(\mathrm{P})}>0 \\
\alpha_{2(\mathrm{P})}<0\end{array}$ & $\begin{array}{c}\text { Female (Zambia) } \\
\text { Relative Female-Male } \\
\text { (Zambia) }\end{array}$ & & & & \\
\hline$\alpha_{2(\mathrm{P})}>0$ & Female (Unskilled) & $\begin{array}{l}\text { Adoption of Export- } \\
\text { Led Strategies }\end{array}$ & $\begin{array}{c}\text { Manufacturing } \\
\text { (Maquilas) }\end{array}$ & $\begin{array}{c}\text { Mexico, } \\
1993\end{array}$ & EC, WS \\
\hline$\alpha_{1} \approx 0$ & Relative Female-Male & $\begin{array}{l}\text { Adoption of Export- } \\
\text { Led Strategies }\end{array}$ & Cross-Sector & $\begin{array}{l}\text { Mexico, } \\
\text { 1987-1993 }\end{array}$ & $\begin{array}{c}\text { EC, WS- } \\
\text { HS }\end{array}$ \\
\hline$\alpha_{1}>0$ & $\begin{array}{c}\text { Female } \\
\text { Relative Female-Male }\end{array}$ & Promotion of EPZs & $\begin{array}{c}\text { Manufacturing } \\
\text { (EPZs) }\end{array}$ & $\begin{array}{l}\text { Madagascar, } \\
\text { 1995-2002 }\end{array}$ & EC, WS \\
\hline$\alpha_{1}>0$ & Female & $\begin{array}{l}\text { Adoption of Export- } \\
\text { Led Strategies }\end{array}$ & $\begin{array}{c}\text { Manufacturing } \\
\text { (Textiles) }\end{array}$ & $\begin{array}{l}\text { Bangladesh, } \\
\text { 1980s-2001 }\end{array}$ & DS, HS \\
\hline$\alpha_{1}>0$ & Relative Female-Male & $\begin{array}{l}\text { Imports in Output per } \\
\text { Industry }\end{array}$ & Manufacturing & $\begin{array}{c}\text { US, } \\
1976-1993\end{array}$ & $\mathrm{EC}, \mathrm{NA}$ \\
\hline$\alpha_{1}>0$ & Female & $\begin{array}{l}\text { Market Liberalisation } \\
\text { (Firm Level) }\end{array}$ & Cross-Sector & $\begin{array}{c}\text { China, } \\
1992\end{array}$ & EC, WS \\
\hline$\alpha_{1}<0$ & Relative Female-Male & & & & \\
\hline$\alpha_{1}<0$ & Relative Female-Male & $\begin{array}{l}\text { Imports and Exports } \\
\text { in Output per } \\
\text { industry }\end{array}$ & Manufacturing & $\begin{array}{c}\text { India, } \\
1983-2004\end{array}$ & $\mathrm{EC}, \mathrm{HS}$ \\
\hline $\begin{array}{l}\alpha_{1}>0 \\
\alpha_{1}<0\end{array}$ & $\begin{array}{c}\text { Female } \\
\text { Relative Female-Male }\end{array}$ & $\begin{array}{l}\text { Adoption of Export- } \\
\text { Led Strategies }\end{array}$ & $\begin{array}{c}\text { Manufacturing } \\
\text { (Textiles) }\end{array}$ & $\begin{array}{c}\text { Madagascar, } \\
1997,1999 \\
\end{array}$ & EC, HS \\
\hline $\begin{array}{c}\alpha_{1}>0 \\
\alpha_{2(\mathrm{Y})}>0\end{array}$ & $\begin{array}{l}\text { Relative Female-Male } \\
\text { Relative Female-Male }\end{array}$ & $\begin{array}{l}\text { Imports and Exports } \\
\text { in GDP, FDI in GDP }\end{array}$ & Cross-Sector & $\begin{array}{c}\text { D1, D2, } \\
1983-1999\end{array}$ & $\mathrm{EC}, \mathrm{NA}$ \\
\hline$\alpha_{1}<0$ & Relative Female-Male & $\begin{array}{l}\text { Adoption of Export- } \\
\text { Led Strategies }\end{array}$ & $\begin{array}{c}\text { Manufacturing } \\
\text { (Textiles) }\end{array}$ & $\begin{array}{l}\text { Bangladesh, } \\
1990,1993,\end{array}$ & DS, CS \\
\hline
\end{tabular}


(2000)

Santos and

\begin{tabular}{|c|c|c|c|c|c|}
\hline & & & \multicolumn{3}{|c|}{1997} \\
\hline$\alpha_{1}>0$ & $\begin{array}{c}\text { Relative Female-Male } \\
\text { (Overall) }\end{array}$ & Expansion of Sector & $\begin{array}{l}\text { Services } \\
\text { (Tourism) }\end{array}$ & $\begin{array}{l}\text { Portugal, } \\
2000\end{array}$ & EC, WS \\
\hline$\alpha_{1}<0$ & $\begin{array}{c}\text { Relative Female-Male } \\
\text { (Tourism) }\end{array}$ & & & & \\
\hline $\begin{array}{c}\alpha_{2(\mathrm{P})}<0 \\
\alpha_{1}>0\end{array}$ & $\begin{array}{c}\text { Female (Unskilled) } \\
\text { Relative Female-Male }\end{array}$ & Reduction of Tariffs & Cross-Sector & $\begin{array}{c}\text { Pakistan, } \\
1993\end{array}$ & CGE \\
\hline$\alpha_{1}<0$ & Relative Female-Male & Expansion of Sector & $\begin{array}{l}\text { Services } \\
\text { (Tourism) }\end{array}$ & $\begin{array}{l}\text { Norway, } \\
\text { 1994-2002 }\end{array}$ & $\mathrm{EC}, \mathrm{WS}$ \\
\hline$\alpha_{1}>0$ & Female & $\begin{array}{l}\text { Adoption of Export- } \\
\text { Led Strategies }\end{array}$ & $\begin{array}{l}\text { Manufacturing } \\
\text { (Maquilas) }\end{array}$ & Mexico, 1990s & CS \\
\hline
\end{tabular}

Varejão (2007) (Maquilas)

Siddiqui (2009)

Thrane (2008)

Tiano (1994)

Abbreviations: CGE: Computer General Equilibrium Model, CS: Case-Study, D1: Developing Countries, D2: Developed Countries, DS: Descriptive Statistics, EC: Econometrics Analysis, EPZ: Export-Processing Zone, FDI: Foreign Direct Investment, GDP: Gross Domestic Product, HB: Home-Based Work, HS: Household Survey, LR: Literature Review, NA: National Accounts, NGF: No Geographic Focus, NTA: Non-Traditional Agriculture, WS: Worker Survey 
Ding et al.

(2009)

Ederington et al.

(2009)



Fontana (2007)

Ghiara (1999)

Kabeer and

Mahmud (2004)

Kongar (2007)

Kucera and

Milberg (2000)

Özler (2001)

Özler (2007)

Table 2. Studies of the effect of trade on employment

$\begin{array}{ccccc}\text { Direction } & \text { Measure of } & \text { Measure of } & \text { Geographical } & \text { Type of } \\ \text { of effect } & \text { Employment } & \text { Openness } & \text { Focus } & \text { Study }\end{array}$

$\alpha_{1}>0 \quad$ Relative Female-Male $\quad$ Imports and Exports Overall Economy $\quad$ Pakistan, EC, NA

\begin{tabular}{|c|c|c|c|c|c|}
\hline$\alpha_{1}>0$ & Female & $\begin{array}{l}\text { Adoption of Export- } \\
\text { Led Strategies }\end{array}$ & $\begin{array}{l}\text { Manufacturing } \\
\text { HV Agriculture }\end{array}$ & NGF & LR \\
\hline $\begin{array}{c}\alpha_{2(\mathrm{P})}>0 \\
\alpha_{2(\mathrm{P})}<0 \\
\alpha_{1}<0\end{array}$ & $\begin{array}{c}\text { Female (Unskilled) } \\
\text { Female (Skilled) } \\
\text { Relative Female-Male }\end{array}$ & $\begin{array}{l}\text { Net Exports in } \\
\text { Output per Industry }\end{array}$ & Manufacturing & $\begin{array}{c}\text { India, } \\
\text { 1983-2000 }\end{array}$ & $\begin{array}{c}\text { EC, WS, } \\
\text { DS, } \\
\text { IOFA }\end{array}$ \\
\hline
\end{tabular}

$\alpha_{2(\mathrm{P})}<0 \quad$ Female (Unskilled)

Services

$\alpha_{2(\mathrm{P})}>0 \quad$ Female (Skilled)

$\alpha_{1}<0 \quad$ Relative Female-Male

$\alpha_{1}<0 \quad$ Relative Female-Male $\quad$ Adoption of Export- $\quad$ Cross-Sector $\quad$ China, DS, HS

(married women, $\quad$ Led Strategies 1995-2002

$$
\text { men) }
$$

\begin{tabular}{|c|c|c|c|c|c|}
\hline$\alpha_{1}>0$ & $\begin{array}{l}\text { Relative Female-Male } \\
\text { (Overall) }\end{array}$ & $\begin{array}{l}\text { Exports in Output per } \\
\text { Industry }\end{array}$ & Manufacturing & $\begin{array}{l}\text { Colombia, } \\
\text { 1984-1991 }\end{array}$ & $\mathrm{EC}, \mathrm{NA}$ \\
\hline$\alpha_{2(\mathrm{P})}<0$ & $\begin{array}{c}\text { Relative Female-Male } \\
\text { (Capital-Intensive } \\
\text { Sectors) }\end{array}$ & & & & \\
\hline
\end{tabular}
Sectors)

\begin{tabular}{|c|c|c|c|c|c|}
\hline $\begin{array}{l}\alpha_{2(\mathrm{P})}>0 \\
\alpha_{2(\mathrm{P})}<0\end{array}$ & $\begin{array}{c}\text { Female Overall (B), } \\
\text { Female Garments (B), } \\
\text { Female } \\
\text { Manufacturing (B) }\end{array}$ & $\begin{array}{c}\text { Abolition of Tariffs } \\
\text { and Depreciation of } \\
\text { Exchange Rate }\end{array}$ & Cross-Sector & $\begin{array}{c}\text { Bangladesh } \\
\text { (B), 1994; } \\
\text { Zambia (Z), } \\
1995\end{array}$ & CGE \\
\hline
\end{tabular}

$\alpha_{2(\mathrm{P})}>0 \quad$ Female Overall (Z),

Female Mining $(Z)$ Female

Manufacturing (Z)

$\alpha_{2(\mathrm{P})}<0 \quad$ Relative Female-Male (Z)

\begin{tabular}{|c|c|c|c|c|c|}
\hline$\alpha_{1}<0$ & Female & $\begin{array}{l}\text { Adoption of Export- } \\
\text { Led Strategies }\end{array}$ & Trade Sectors & $\begin{array}{c}\text { Mexico, } \\
1987-1993\end{array}$ & $\begin{array}{l}\text { EC, WS- } \\
\text { HS }\end{array}$ \\
\hline$\alpha_{1}>0$ & Female & $\begin{array}{l}\text { Adoption of Export- } \\
\text { Led Strategies }\end{array}$ & $\begin{array}{c}\text { Manufacturing } \\
\text { (Textiles) }\end{array}$ & $\begin{array}{l}\text { Bangladesh, } \\
\text { 1980s-2001 }\end{array}$ & DS, HS \\
\hline $\begin{array}{c}\alpha_{1}<0 \\
\alpha_{2(\mathrm{P})}<0 \\
\alpha_{2(\mathrm{P})}>0 \\
\alpha_{1}<0\end{array}$ & $\begin{array}{l}\text { Female (overall) } \\
\text { Female (Unskilled) } \\
\text { Female (Skilled) } \\
\text { Relative Female-Male }\end{array}$ & $\begin{array}{l}\text { Imports in Output per } \\
\text { Industry }\end{array}$ & Manufacturing & $\begin{array}{c}\text { US, } \\
1976-1993\end{array}$ & $\mathrm{EC}, \mathrm{NA}$ \\
\hline$\alpha_{1}<0$ & Relative Female-Male & $\begin{array}{l}\text { Increase in Net } \\
\text { Exports }\end{array}$ & $\begin{array}{c}\text { Manufacturing } \\
\text { (Textiles) }\end{array}$ & $\begin{array}{c}\text { OECD, } \\
1978-1995\end{array}$ & IOFA/DS \\
\hline $\begin{array}{c}\alpha_{1}>0 \\
\alpha_{2(\mathrm{P})}>0 \\
\alpha_{2(\mathrm{P})}<0\end{array}$ & $\begin{array}{c}\text { Relative Female-Male } \\
\text { Relative Female-Male } \\
\text { (Unskilled) } \\
\text { Relative Female-Male } \\
\text { (Capital-Intensive } \\
\text { Sectors) }\end{array}$ & $\begin{array}{l}\text { Exports in Output per } \\
\text { Industry }\end{array}$ & Manufacturing & $\begin{array}{c}\text { Turkey, } \\
\text { 1983-1985 }\end{array}$ & $\mathrm{EC}, \mathrm{NA}$ \\
\hline $\begin{array}{c}\alpha_{1}>0 \\
\alpha_{2(\mathrm{P})}>0\end{array}$ & $\begin{array}{l}\text { Relative Female-Male } \\
\text { Relative Female-Male }\end{array}$ & $\begin{array}{l}\text { Adoption of Export- } \\
\text { Led Strategies }\end{array}$ & Manufacturing & $\begin{array}{c}\text { Turkey, } \\
1986-1996\end{array}$ & DS \\
\hline
\end{tabular}


(Skilled)

Rani and Unni

(2009)

$\begin{array}{cc}\alpha_{1}<0 \quad \text { Relative Female-Male } & \begin{array}{c}\text { Adoption of Export- } \\ \text { Led Strategies }\end{array} \\ \end{array}$

Manufacturing

(Home-based

India,

EC, WS

Subcontracting)

1994-1995,

Siddiqui (2009)

$\begin{array}{ccc}\alpha_{2(\mathrm{P})}>0 & \text { Female (Unskilled) } & \text { Reduction of Tariffs } \\ \alpha_{1}<0 & \text { Female (Overall) }\end{array}$

Cross-Sector

2000-2001

$\alpha_{1}<0 \quad$ Relative Female-Male

Standing (1999)

$\alpha_{1}<0$

Female

Adoption of Export-

Manufacturing

Pakistan,

CGE

$\alpha_{1}>0 \quad$ Relative Female-Male Led Strategies (Textiles)

Tucker (2007)

$\alpha_{1}<0$

Relative Female-Male

Expansion of Sector

Services (Tourism)

D1, D2: NGF,

DS

von Braun et al.

(1994)

Wilson (2008)

\begin{tabular}{cccccc}
\hline$\alpha_{1}<0$ & Relative Female-Male & $\begin{array}{c}\text { Commercialisation, } \\
\text { New Technologies }\end{array}$ & Agriculture & The Gambia, & CS, EC, \\
& Relative Female-Male & Expansion of Sector & Services (Tourism) & $\begin{array}{c}\text { Mexico } \\
\text { HS }\end{array}$ & DS \\
\hline$\alpha_{1}<0$ & Relative Female-Male & $\begin{array}{c}\text { Adoption of Export- } \\
\text { Led Strategies }\end{array}$ & Agriculture & Zambia, 1990s & CS/DS \\
\hline$\alpha_{1}<0$ & & & &
\end{tabular}

Wold (1997) Led Strategies

Abbreviations: CGE: Computer General Equilibrium Model, CS: Case-Study, D1: Developing Countries, D2: Developed Countries, DS: Descriptive Statistics, EC: Econometrics Analysis, ES: Ethnographic Study, HS: Household Survey, HV: High-Value, IOFA: Input-Output Factor Analysis, LR: Literature Review, NA: National Accounts, NGF: No Geographic Focus, WS: Worker Survey 